\title{
ACCOUNTING PRACTITIONERS PERCEPTION OVER THE IMPACT OF IFRS IMPLEMENTATION ON THE PERFORMANCE OF ENTITIES IN THE CONSTRUCTION SECTOR FROM THE WESTERN REGION OF ROMANIA
}

\author{
Oana Bogdan \\ Ph.D., Research assistant, Faculty of Economics and Business Administration, Timisoara, \\ e-mail: oana.bogdan@e-uvt.ro \\ Dorel Mateş \\ Professor, Faculty of Economics and Business Administration, Timisoara, \\ e-mail: dorel.mates@e-uvt.ro \\ Aura Emanuela Domil \\ Associate Professor, Faculty of Economics and Business Administration, Timisoara, \\ e-mail: aura.domil@e-uvt.ro \\ Marina Adriana Puşcaş \\ „Vasile Goldiş” Western University of Arad \\ Ancuța Pușcaș \\ University „1 Decembrie 1918” of Alba Iulia \\ Ramona Teşu \\ Chartered accountant
}

(Received, September 2017; Accepted, November 2017)

\begin{abstract}
Through this paper, we want to identify the correlations between the benefits and costs of adopting IFRS standards in construction entities in the Western Region of Romania and their performance, using the Pearson correlation coefficient, which measures and describes the direction, degree and form of the association between two variables, thus obtaining high, reasonable, weak and very weak links between the benefits / costs and the performance of the entity.

The tool used in the research undertaken by construction companies is the questionnaire. The questionnaire "On the Costs and Benefits of IFRS in Construction Companies in the Western Region of Romania" was disseminated among professional accountants in order to identify the perceptions of economists operating in construction companies in the Western Region Romania on the costs and benefits of implementing international standards.

Thus, through this paper we aim to identify the correlations between the following benefits and costs:

- Benefits of implementation: comparability of information, increased transparency, increased access to capital, cost savings, reduction of informational asymmetry,

- Implementation costs: IFRS readiness level, complexity of standards, link between accounting and taxation, existing accounting tradition, costs associated with IFRS conversion, and
\end{abstract}

26 Studia Universitatis "Vasile Goldis" Arad. Economics Series Vol 27 Issue 4/2017

ISSN: 1584-2339; (online) ISSN: $2285-3065$

Web: publicatii.uvvg.ro/index.php/studiaeconomia.Pages $26-36$ 
Bogdan O., Mateș D., Domil A.E., Puşcas M.A., Pușcas A. (2017)

Accounting practitioners perception over the impact of IFRS implementation on the performance of entities in the construction sector from the western region of Romania

- Performance of the entity viewed from the perspective of: total revenue and turnover. In the research, we chose to present the analysis of compared to both the total revenues and the turnover, because the difference between the two economic-fiscal indicators is mainly represented by the financial revenues and the incomes from the disposals of assets.

Key words: IFRS, benefits, costs, correlations, Pearson

JEL CODES: M41 - Accounting

\section{Introduction}

Globalization is the most important factor in the alignment of national accounting rules to IFRSs. The accounting's role is to provide the necessary information in order to take decisions regarding the financial position, the performances and the changes in financial position of the economic entity. (Cernusca \& David, 2016, p. 64) If entities listed on regulated markets of the European Union have to prepare consolidated IFRS financial statements starting with 2005, in Romania, the first experiences with international standards occurred immediately after 2000, rather in the form of a convergence process. Romania's accession to the European Union has led to O.M.F.P. no. 1121/2006, on the basis of which entities whose securities are traded on a regulated market and prepare consolidated statements are required from 2007 to use IFRS. From 2012, by issuing the M.F.P. no. 881/2012, entities are required to apply IFRSs when compiling individual annual financial statements, and O.M.F.P. no. 1286/2012 elaborated for the approval of accounting regulations complying with IFRS addresses to companies whose securities are admitted to trading on a regulated market.

Based on this order, companies must prepare individual financial reports in accordance with IFRS in national currency and in Romanian language and be the subject to statutory audit. If, in the future, securities are no longer admitted to a regulated market for trading, the entities must nevertheless ensure the continuity of application of international standards. IASB (International Accounting Standards Board) is the global accounting standard-setting body assuming the central role on coordinating the international accounting convergence process (Burca \& Cotlet, 2014, p.73).

O.M.F.P. no. 881/2012 supports the strategy to increase the implementation of IFRS in the Romanian environment, so that starting with 2012, credit institutions in Romania are obliged to use IFRS as the basis of accounting. Moreover, through the C.N.V.M. no. 116/2011 and the companies authorized, supervised and regulated by C.N.V.M. are required to prepare for 2011 and for 2012 another set of financial statements, using the IFRS, for indicative purposes, obtained by restating the information issued in accordance with the national rules. A.S.F. require entities to disclose and differences between existing accounting treatments between the two 
Bogdan O., Mateș D., Domil A.E., Pușcaș M.A., Pușcaş A. (2017)

Accounting practitioners perception over the impact of IFRS implementation on the performance of entities in the construction sector from the western region of Romania

regulations, respectively IFRS and national regulation in force, on each component of the situation together with the related explanations.

As the standards are used as a basis for accounting, the Minister of Public Finance issued Order no. 1286/2012(currently replaced by Order no. 2844/2016 for the approval of the Accounting Regulation in compliance with the International Financial Reporting Standards) regulating the following aspects regarding the application of IFRS in companies:

- presentation of the rules for the preparation, audit and publication of financial reports;

- provisions related to the Administrators' Report;

- $\quad$ specific economic and financial operations;

- the plan of accounts in accordance with IFRS.

Taking into account the IFRS alignment process and the fact that there are not many companies in Romania yet applying these international standards, we considered it appropriate to find out what the perception of professional accountants operating in the construction companies in the West Region of Romania on the process of harmonization and compliance of Romanian accounting with IFRSs in order to find out the benefits and costs of this process and the impact on the performance of entities. We chose the Western Region to carry out the research because it is an area with very high foreign direct investments compared to the rest of the country and the level of economic development is higher.

Empirical research was conducted to determine the perception of accountancy professionals in construction entities about the main benefits and costs of adopting international standards, and to assess the impact of accounting harmonization on entity performance, given the perceptions of practitioners.

Within the scientific approach we applied the following research methodologies:

- Quantitative: via the questionnaire;

- Qualitative: through the interview and the case study carried out among the companies in the field of construction that have their headquarters in the western part of the country, namely Timis, Arad, Caraş-Severin and Hunedoara counties, as well as companies having their registered office in other counties in the country, but have secondary offices in the western region of the country. These entities have been included in the study because they have activity in the Western area of Romania and are relevant from this perspective.

Also, in the research, we have considered both a descriptive and an exploratory approach. Thus, the descriptive approach was made through the questionnaire as a research tool. This study was doubled by conducting interviews with each approved person who agreed to respond in writing to the questionnaire questions. 
Bogdan O., Mateș D., Domil A.E., Pușcaş M.A., Puşcaş A. (2017)

Accounting practitioners perception over the impact of IFRS implementation on the performance of entities in the construction sector from the western region of Romania

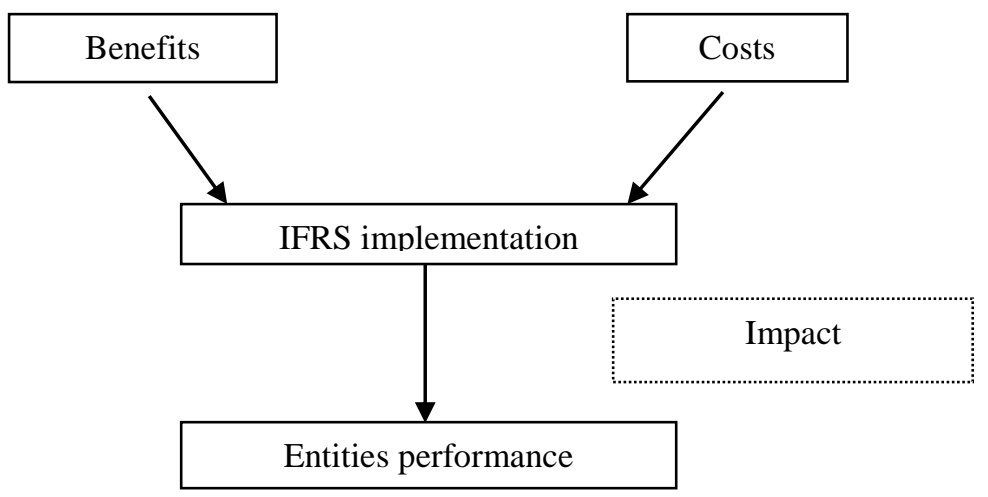

Figure 1. The research model analyzed

Source: author's view

\section{The Research Methodology}

The questionnaire on the costs and benefits of IFRS in construction companies in the Western Region of Romania was disseminated among the professional accountants in this area of the country, namely Timiş, Arad, Caras-Severin and Hunedoara counties. between November 2015 and May 2016. The purpose of the questionnaire is to identify the perception of professional accountants operating in construction companies in the Western Region of Romania regarding the costs and benefits of implementing IFRSs and measuring the impact of adoption on the performance of the entity. In order to carry out the research, we distributed the questionnaire in a total of 300 copies, of which 105 respondents completed the survey, 80 entities belonging to the micro-entities and small entities and 25 companies classified as medium-sized entities and large, resulting in a 35\% response rate.

Correlations will be calculated using the Pearson correlation coefficient in Microsoft Office Excel.

This Pearson correlation coefficient compares the degree of linear association between variables, being a statistical measurement technique.

Bolboaca, quoted by the Armenian in his research paper (2015), presents the characteristics of this linear correlation:

- direction: positive; negative;

- degree of association: values between -1 and +1 , the absolute value indicating the strength of the association;

- direction of association: $(-)=$ negative direction; 
Bogdan O., Mateș D., Domil A.E., Pușcaş M.A., Puşcaş A. (2017)

Accounting practitioners perception over the impact of IFRS implementation on the performance of entities in the construction sector from the western region of Romania

$(+)=$ positive direction

- the form of correlation: linear;nonlinear.

- formula: $\quad r=\frac{\sum(\mathrm{x}-\overline{\mathrm{x}})(\mathrm{y}-\overline{\mathrm{y}})}{\sqrt{\sum(\mathrm{x}-\overline{\mathrm{x}})^{2} \sum(\mathrm{y}-\overline{\mathrm{y}})^{2}}}$

- where:

$\mathrm{X}=\mathrm{x} 1, \mathrm{x} 2, \ldots, \mathrm{xn}$ and $\mathrm{Y}=\mathrm{y} 1, \mathrm{y} 2, . ., \mathrm{yn}$ are the measured values, and $\overline{\mathrm{X}}, \overline{\mathrm{Y}}$ are the sampling averages of the respective series.

- the interpretation of the formula:

$\mathrm{r} \in[0 ; 0,2]=$ very poor correlation;

$\mathrm{r} \in[0,2 ; 0,4]=$ poor correlation;

$\mathrm{r} \in[0,4 ; 0,6]=$ reasonable correlation;

$\mathrm{r} \in[0,6 ; 0,8]=$ high correlation;

$\mathrm{r} \in[0,8 ; 1]=$ very high correlation.

The main objective of the paper is to identify the correlations between the benefits and costs of adopting IFRS in the construction entities in the Western Region of Romania and their performance in view of the perceptions of the professional accountants active in the micro-entities and small entities and those who work in medium and large entities.

\section{Research hypotheses and correlations between variables}

The first correlation that we plan to analyse is represented by the link between the benefits of the process of accounting harmonisation and conformity through IFRS and the performance of the companies that use these standards.

For this purpose, we propose the following hypotheses:

Hypothesis H1: There is a positive link between the benefits of the process of accounting harmonization and conformity through IFRS and the performance of companies. We believe that, in time, the benefits of this implementation will improve the performance of the involved entities.

- $\mathrm{H}_{1.1}$ : The comparability of financial information with the help of IFRS has a positive effect on the performance of the entity;

- $\mathrm{H}_{1.2}$ : The high level of transparency has a positive effect on the performance of the entity;

- $\mathrm{H}_{1.3}$ : The facilitation of access to capital by implementing IFRS has a positive effect on the performance of the entity:

- $\mathrm{H}_{1.4}$ : The reduction of information asymmetry by implementing IFRS has a positive effect on the performance of the entity;

- $\mathrm{H}_{1.5}$ : The cost reduction achieved due to the implementation of IFRS has a positive effect on the performance of the entity; 
Bogdan O., Mateş D., Domil A.E., Puşcaş M.A., Puşcaş A. (2017)

Accounting practitioners perception over the impact of IFRS implementation on the performance of entities in the construction sector from the western region of Romania

The second correlation subjected to analysis is represented by the link between the costs involved by the process of accounting harmonization and conformity through IFRS and the performance of the companies that use these standards.

For this purpose, we propose the following hypotheses:

Hypothesis $\boldsymbol{H}_{2}$ : There is a negative link between the costs involved by the process of accounting harmonization and conformity through IFRS and the performance of companies. We believe that, at the beginning of the process of adopting the international standards, the costs of implementation will reduce the performance of the entities:

- $\mathrm{H}_{2.1}$ : The low professional competency of professional accountants in the field of IFRS has a negative effect on the performance of the entity;

- $\mathrm{H}_{2.2}$ : The dependency of accounting to a fiscal system has a negative effect on the performance of the entity;

- $\mathrm{H}_{2.3}$ : The high costs associated with converting to IFRS have a negative effect on the performance of entities;

- $\mathrm{H}_{2.4}$ : The complexity of IFRS has a negative effect on the performance of entities;

- $\quad \mathrm{H}_{2.5}$ : The influence of existing accounting traditions has a negative effect on the performance of entities;

Hypothesis $\boldsymbol{H}_{3}$ : The benefits of adopting IFRS are higher than the costs needed for the implementation of IFRS.

The results obtained from the calculations are as follows:

Tabel 1.

Correlations between variables using the Pearson coefficient

\begin{tabular}{|l|c|c|c|c|}
\hline \multicolumn{1}{|c|}{$\begin{array}{c}\text { Benefits and costs I } \\
\text { Performance indicators }\end{array}$} & \multicolumn{2}{c|}{ Revenue } & \multicolumn{2}{c|}{ Turnover } \\
\cline { 2 - 5 } & $\mathbf{A}$ & $\mathbf{B}$ & $\mathbf{C}$ & $\mathbf{D}$ \\
\hline The comparability of financial information & 0,51 & 0,74 & 0,66 & 0,61 \\
\hline The high level of transparency & 0,76 & 0,84 & 0,97 & 0,91 \\
\hline The facilitation of access to capital & 0,29 & 0,88 & 0,54 & 0,83 \\
\hline The reduction of information asymmetry & 0,80 & 0,74 & 0,84 & 0,69 \\
\hline The cost reduction achieved due to the implementation of IFRS & 0,62 & 0,92 & 0,78 & 0,77 \\
\hline The low professional competency of professional accountants & 0,78 & 0,74 & 0,79 & 0,54 \\
\hline The dependency of accounting & 0,47 & 0,58 & 0,41 & 0,47 \\
\hline The high costs associated with converting to IFRS & 0,58 & 0,03 & 0,51 & 0,12 \\
\hline The complexity of IFRS & 0,59 & 0,34 & 0,48 & 0,25 \\
\hline The influence of existing accounting traditions & 0,81 & 0,82 & 0,86 & 0,79 \\
\hline
\end{tabular}

A - Micro entities and small entities

B - Medium and large entities

C - Micro entities and small entities

D - Medium and large entities

Source: author's view

DE GRUYTER OPEN
Studia Universitatis "Vasile Goldis" Arad. Economics Series Vol 27 Issue 4/2017 ISSN: 1584-2339; (online) ISSN: 2285 - 3065 
Bogdan O., Mateș D., Domil A.E., Puşcaş M.A., Pușcaş A. (2017)

Accounting practitioners perception over the impact of IFRS implementation on the performance of entities in the construction sector from the western region of Romania

\section{Results and discussion}

- The overall correlation of benefits of IFRS implementation and entity performance

$$
\begin{aligned}
& \text { PB. IFRS. Micro entities and small entities }=\frac{6,77}{5 * 2}=0,68 \\
& \text { PB. IFRS. Medium and large entities }=\frac{7,93}{5 * 2}=0,79
\end{aligned}
$$

Starting from the perception of professional accountants regarding the benefits of IFRS implementation and having regard to the ranking of their importance for construction entities in the Western Region of Romania, we have come to the following conclusions:

[1] Given the benefits of implementing IFRS and entity performance, from the perspective of professional accountants in micro entities and small entities, using the Pearson correlation - we note that there is a direct and positive link between the two variables. The result, 0.68 , reflects that the benefits of adopting IFRSs and the performance of entities are largely correlated, reflecting the fact that the five benefits presented can largely determine the increase in total revenue and turnover. [2] at the level of the medium and large entities, we note that direct, positive and strong links are also established between the two variables due to the value of 0.79 . [3] From the calculations we see that respondents in medium and large entities attach greater importance to the five criteria for generating benefits for the entity, as compared to professional accountants from micro-entities and small entities.

- The overall correlation of the costs of IFRS implementation and entity performance

$$
\begin{aligned}
& \text { PC. IFRS. Micro entities and small entities }=\frac{6,28}{5 * 2}=0,63 \\
& \text { PC. IFRS. Medium and large entities }=\frac{4,68}{5 * 2}=0,47
\end{aligned}
$$

Starting from the perception of professional accountants related to the obstacles to the implementation of IFRS and considering their importance for construction entities in the Western region of Romania, we came to the following conclusions:

[1] given the costs of implementing IFRS and the performance of the entity using them, through Pearson's correlation - we note that there is a direct and positive link between the two variables. The result obtained, the value of 0.63 reflects the fact that for micro-entities and small entities the obstacles to the adoption of IFRSs and the performance of entities are correlated to a high level.

[2] analyzing the responses of medium and large entities, we note that there is a direct, positive, reasonable link between the five obstacles presented and the performance of the entity. 
Bogdan O., Mateş D., Domil A.E., Puşcaş M.A., Puşcaş A. (2017)

Accounting practitioners perception over the impact of IFRS implementation on the performance of entities in the construction sector from the western region of Romania

[3] by comparing the results we can see that the obstacles to the adoption of IFRS are higher for micro-entities than for medium and large entities

Tabel.2.

Validation or invalidation of research hypotheses

\begin{tabular}{|c|l|c|}
\hline $\begin{array}{c}\text { Nr. } \\
\text { crt }\end{array}$ & \multicolumn{1}{|c|}{ Hypothesis } & $\begin{array}{c}\text { VALIDATE / } \\
\text { INVALIDATE }\end{array}$ \\
\hline 1 & $\begin{array}{l}\text { The comparability of financial information through IFRSs has } \\
\text { a positive effect on the performance of the entity }\end{array}$ & VALIDATE \\
\hline 2 & $\begin{array}{l}\text { The high level of transparency has a positive effect on the } \\
\text { performance of the entity }\end{array}$ & VALIDATE \\
\hline 3 & $\begin{array}{l}\text { Facilitating access to capital through the implementation of } \\
\text { IFRS has a positive effect on the performance of the entity }\end{array}$ & VALIDATE \\
\hline 4 & $\begin{array}{l}\text { Reducing information asymmetries by implementing IFRSs } \\
\text { has a positive effect on entity performance }\end{array}$ & VALIDATE \\
\hline 5 & $\begin{array}{l}\text { Reducing information asymmetries by implementing IFRSs } \\
\text { has a positive effect on entity performance }\end{array}$ & VALIDATE \\
\hline 6 & $\begin{array}{l}\text { The low level of training of the professional accountant in IFRS } \\
\text { has a negative effect on the performance of the entity }\end{array}$ & VALIDATE \\
\hline 7 & $\begin{array}{l}\text { Dependency of tax accounting has a negative effect on the } \\
\text { performance of the entity }\end{array}$ & VALIDATE \\
\hline 8 & $\begin{array}{l}\text { The high costs associated with IFRS conversion have a negative } \\
\text { impact on entity performance }\end{array}$ & INVALIDATE \\
\hline 9 & $\begin{array}{l}\text { The complexity of IFRSs has a negative effect on entity } \\
\text { performance }\end{array}$ & VALIDATE \\
\hline 10 & $\begin{array}{l}\text { The influence of the accounting tradition has a negative effect } \\
\text { on the performance of the entity }\end{array}$ & VALIDATE \\
\hline 11 & $\begin{array}{l}\text { The benefits of adopting IFRSs are greater than the costs of } \\
\text { implementing them }\end{array}$ & VALIDATE \\
\hline
\end{tabular}

Source: author's view

- Hypothesis 1: „The ability to compare financial information through IFRS has a positive effect on the performance of the entity" is validated, as there are high connections established between the variables. According to the perception of the respondents, the performance of the entity, considering the benefit of information compatibility, will register a slow growth.

- Hypothesis 2: „A high level of transparency has a positive effect on the performance of the entity" is validated, because very strong connections are established between the variables and they can influence the tendencies of the indicators that reflect the performance of the entity;

- Hypothesis 3 „Facilitating access to capital by implementing IFRS has a positive effect on the performance of the entity" is validated, as there are high connections established between the variables and these can influence the tendencies of the performance indicators;

DE GRUYTER OPEN
Studia Universitatis “Vasile Goldis” Arad. Economics Series Vol 27 Issue 4/2017 ISSN: 1584-2339; (online) ISSN: 2285 - 3065 
Bogdan O., Mateș D., Domil A.E., Puşcaş M.A., Pușcaş A. (2017)

Accounting practitioners perception over the impact of IFRS implementation on the performance of entities in the construction sector from the western region of Romania

- Hypothesis 4 ,Reducing information asymmetry through the implementation of IFRS has a positive effect on the performance of the entity" is validated, as there are high connections established between the variables and these reflect the tendency of performance increase thanks to the benefits of international standards;

- Hypothesis 5 „Reducing costs thanks to the implementation of IFRS has a positive effect on the performance of the entity" is validated, as there are high connections established between the variables and that determine an increased performance of the entity;

- Hypothesis 6, ,The low professional level of professional accountants in the field of IFRS has a negative effect on the performance of the entity" is validated because there are high connections established between the variables, which reflects the fact that the low level of knowledge and professional skills can determine a low performance;

- Hypothesis 7 „The dependency of accounting to a fiscal system has a negative effect on the performance of the entity" is validated because there are moderate links established between variables and they can influence the value of the indicators;

- Hypothesis 8 „The high costs associated to the conversion to IFRS have a negative effect on the performance of the entities" is not validated because of the very weak connections established between the variables and that cannot determine a lowering in performance;

- Hypothesis 9 "The complexity of IFRS has a negative effect on the performance of the entities" is validated, as there are moderate links established between the variables and these can influence the values of economic-financial indicators;

- Hypothesis 10 „The influence of existing accounting tradition has a negative effect on the performance of the entity" is validated, as there are very high connections between the variables and these can influence the indicators;

- Hypothesis 11 „The benefits of implementing IFRS outweigh the costs of their adoption" is validated, due to the results shown by using the Pearson correlation coefficient.

\section{Conclusions}

In the research, we wanted to identify, with the help of the Pearson correlation, the links that exist between the benefits, the obstacles to the implementation of IFRSs and the performance of the entity:

[1] the links between the five benefits of implementing IFRS analyzed and the performance of the entity, expressed as: total revenue and turnover; 
Bogdan O., Mateș D., Domil A.E., Pușcas M.A., Pușcas A. (2017)

Accounting practitioners perception over the impact of IFRS implementation on the performance of entities in the construction sector from the western region of Romania

[2] links between the 5 identified obstacles and the performance expressed as: total revenue and turnover.

The results showed that there are direct (positive) links of these variables with different intensities: very high, high, reasonable, weak and very weak.Considering the literature consulted for this paper, as well as the results of the empirical research, we can issue the following opinions regarding the arguments for adopting IFRS for entities in the construction field in the West region of Romania. Therefore, by adopting IFRS:

- the compatibility of financial information is ensured;

- access to international and capital markets is facilitated;

- the capital market in Romania is developed;

- homogenous accounting regulations are used;

- a harmonisation with international standards, known as ,positive examples”, is achieved; this offers a high degree of credibility compared to national regulations;

- the premises for attracting foreign investments are created;

- financial stability is assured;

- new opportunities for societies in the construction field are created;

- a common, universal accounting language will be used, that can create the opportunity that professional accountants will be able to do their job from anywhere in the world, no matter where they were schooled;

We believe that the adoption of international standards will become unavoidable in the context in which national bodies will not elaborate qualitative regulations. The fact that professional accountants active in this field are open to this trend is a very important aspect in the process of accounting harmonisation.

\section{References}

[1] Burca, V., Cotlet, D. (2014). Considerations on IASB Recent Issued Standards. Studia Universitatis „Vasile Goldis” Arad, Vol.24, No 1, 72-95.

[2] Cernusca L., David D., Nicolaescu C., Gomoi B. (2016). Empirical study on creative accounting phenomenon. Studia Universitatis „Vasile Goldis” Arad, Vol.26, Issue 2, 63-87.

[3] Deac M., (2013) Romanian accounting - a tale of two standards, Annals of University of Petroșani, Economics, 13(1);

[4] Mateş D., Domil Aura, Artene A., Hlaciuc Elena, Grosu Veronica, Tamba A., Breban Veronica, Puşcaş Adriana, Ursachi Antonela, Socoliuc M., Bogdan Oana, (2016), Contabilitatea şi gestiunea fiscală a entităţilor economice, ed.Eurostampa, Timişoara;

[5] Păunescu Mirela (2015) Implicaţii fiscale ale Standardelor Internaţionale de Raportare Financiară şi aplicarea IFRS 1, Colecţia cercetare avansată postdoctorală în ştiinţe economice, Ed. ASE, Bucureşti;

Studia Universitatis "Vasile Goldis" Arad. Economics Series Vol 27 Issue 4/2017 ISSN: 1584-2339; (online) ISSN: 2285 - 3065

Web: publicatii.uvvg.ro/index.php/studiaeconomia.Pages $26-36$ 
Bogdan O., Mateş D., Domil A.E., Puşcaş M.A., Puşcaş A. (2017)

Accounting practitioners perception over the impact of IFRS implementation on the performance of entities in the construction sector from the western region of Romania

[6] Rusu Alina, Adoptarea normelor IAS/IFRS - Premisă a creșterii gradului de comparabilitate a informaţiilor prezentate în situaţiile financiare anuale, disponibil online:

http://www.bursedoctorale.ro/public/documente/conferinte/1332930586_articol_ADOPTA REA\%20NORMELOR\%20IAS.pdf

[7] ***O.M.F.P. nr. 1121/2006 privind aplicarea Standardelor Internaţionale de Raportare Financiară, publicat în Monitorul Oficial al României, Partea I, nr. 602 din 12 iulie 2006;

[8] ***O.M.F.P. nr. 881 din 25 iunie 2012 privind aplicarea de către societățile comerciale ale căror valori mobiliare sunt admise la tranzacționare pe o piață reglementată a Standardelor Internaționale de Raportare Financiară emis de MINISTERUL FINANȚELOR PUBLICE PUBLICAT și publicat în MONITORUL OFICIAL NR. 424 din 26 iunie 2012;

[9] *** O.M.F.P. nr. 1.286/2012 pentru aprobarea Reglementărilor contabile conforme cu Standardele internaţionale de raportare financiară, aplicabile societăţilor comerciale ale căror valori mobiliare sunt admise la tranzacţionare pe o piaţă reglementată, publicat în Monitorul Oficial al României, Partea I, nr. 687 şi 687 bis din 4 octombrie 2012, cu modificările şi completările ulterioare;

[10] ***O.M.F.P nr. 2844/2016 din 12 decembrie 2016 pentru aprobarea Reglementărilor contabile conforme cu Standardele Internaţionale de Raportare Financiară publicat în Monitorul Oficial al României, Partea I, nr. 1020 din 19 decembrie 2016

[11]***O.M.F.P. nr. 1802 din 29 decembrie 2014 - Partea I pentru aprobarea Reglementărilor contabile privind situațiile financiare anuale individuale şi situaţiile financiare anuale consolidate publicat în Monitorul Oficial al României, Partea I, nr. 963 din 30 decembrie 2014; 